\title{
鋼構造梁降伏型魚骨多層骨組の損傷分布則 \\ DAMAGE DISTRIBUTION LAW OF WEAK-BEAM TYPE FISHBONE-SHAPED MULTI-STORY STEEL FRAMES
}

\author{
小久保 彰*，半 貫 敏 夫**，秋 山 宏*** \\ Akira KOKUBO, Toshio HANNUKI and Hiroshi AKIYAMA
}

\begin{abstract}
The total energy input into a structure exerted by an earthquake is a very stable amount. Then, it becomes very important to predict the distribution of damage for the seismic design purpose. The damage distribution is influenced by the distribution of the strength and the stiffness ratios of beam to column. In this paper, a basic rule which governs the distribution of damage in weak-beam type multi-story steel structures is derived through elasto-plastic response analysis, and is expressed in a simple formula. Applied analytical model is fishbone-shaped frames. The results of analysis are summarized in a form of the damage concentration index $n$.
\end{abstract}

Keywords : Weak-Beam Type Multi-Story Steel Structures, Fishbone-Shaped Frame Model, Damage Distribution, Stiffness Ratio of Beam and Column, Damage concentration index $n$ 鋼構造梁降伏型多層骨組, 魚骨モデル, 損傷分布, 梁柱剛性比, 損傷集中指数 $\mathrm{n}$

1. 序

地震時に構造物に投入されるエネルギーは、構造物の総質量およ び 1 次固有周期にのみ依存する、非常に安定した量である。構造物 に投入されるエネルギーの総量が、強度や変形特性によらない安定 した量であれば、構造物の各部にエネルギーがどのように分配され

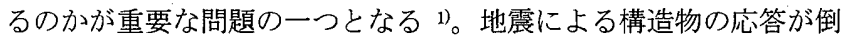
壊に関わるような場合、構造物に投入されるエネルギーの大部分は、 構造物の累積塑性ひずみエネルギー(損傷)として吸収される。多層 骨組の耐震設計において、地震下における多層骨組の損傷分布を支 配する基本則が秋山 2).3)により提唱されている。この基本則は、せ ん断型骨組を対象として、その損傷分布が基準となる層のせん断強 度分布からの各層せん断強度のずれにより、どのように変化するか を示すものである。せん断型骨組モデルは各層の変形特性が着目す る層の層間変位により独立に決定されるため、柱降伏型モデルの評 価には適しているが、上下層の柱の連続性による、梁と柱の変形特 性が影響する梁降伏型モデルを評価するためには、梁の強度変化と 損傷分布の変化が直接表現できず、間接的な手法になっている ${ }^{3) 。}$ 本論文は文献 3) と同様の手法を、部材レベルの変形を評価できる魚 骨モデルに適用し、梁降伏型骨組の損傷分布則を部材レベルの予測 式として示す。柱は弾性に留まるものとする。魚骨モデルの有効性 は文献 4)等で報告されている。

\section{2. 損傷分布の基準状態}

\section{1 基準骨組}

図 1 に梁降伏型の降伏機構を形成する、鋼構造多層多スパン骨組 を代表する梁降伏型魚骨モデルを示す。梁降伏型骨組のエネルギー 吸収は図に示すように、完全弾塑性型の復元力特性を持つ各層上部 梁端部および基礎梁端部の塑性化によるものとする。図中の番号は 節点番号を示す。骨組各層の階高は等しいものとする。また各層の せん断強度分布が最適降伏せん断力係数分布 ${ }^{2)}$ を持つ骨組を想定す る。柱の反曲点は階高の中央にあると仮定し、梁材端のモーメント 分布を求め、このモーメント分布と一致する梁の降伏モーメント分 布を持つ骨組みを基準骨組とする。

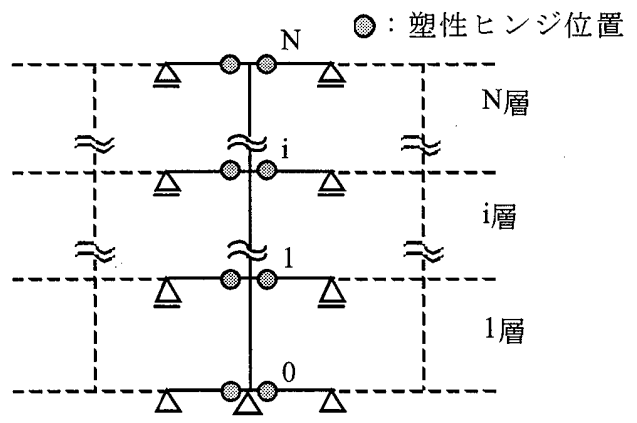

図 1 梁降伏型魚骨モデル
*日本大学大学院理工学研究科建築学専攻 大学院生

** 日本大学理工学部建築学科 教授 . 工博

*** 日本大学総合科学研究所 教授 · 工博
Graduate Student, Architecture Major, Graduate School of Science and Technology, Nihon Univ.

Prof., Dept. of Architecture, Collage of Science and Technology, Nihon Univ., Dr. Eng.

Prof., University Research Center, Nihon Univ., Dr. Eng. 


\section{2 基準状態の骨組}

\section{2.1 基準材端降伏モーメント係数分布 $\bar{\alpha}_{i}$}

基隻骨組における各層の柱頭、柱脚の柱材端モーメント $\mathrm{cM}_{\mathrm{Ui}} 、 \mathrm{c}_{\mathrm{Li}}$ は最適降伏せん断力係数分布 $\bar{\alpha}_{i}$ を用いて、次のように表せる。

$$
\begin{aligned}
& { }_{c} M_{U i}=\sum_{j=i}^{j} m_{j} \cdot \overline{\alpha_{i}} \cdot \frac{H g}{2} \cdot \alpha_{1} \\
& { }_{c} M_{L i}={ }_{c} M_{U i} \\
& \}
\end{aligned}
$$

\section{ここで、 $m_{j}: \mathrm{j}$ 層上部の質点の質量}

魚骨モデル各節点での梁材端降伏モーメントの総和を、最上層上 部 $\mathrm{b}_{\mathrm{M}} \mathrm{MN}$ 、第 1 層下部 $\mathrm{b} \mathrm{MYO}$ 、一般層上部 $\mathrm{b} \mathrm{M}_{\mathrm{Yi}}$ とする。 bM $\mathrm{M}_{\mathrm{ii}}$ はそれぞれ次式となる。第 1 層せん断力係数 $\alpha=1.0$ とする。

$$
\left.\begin{array}{l}
{ }_{b} M_{Y N}={ }_{c} M_{U N}=m_{N} \cdot \overline{\alpha_{N}} \cdot \frac{H g}{2} \cdot \alpha_{1} \\
{ }_{b} M_{Y 0}={ }_{c} M_{L 1}=M \cdot \overline{\alpha_{1}} \cdot \frac{H g}{2} \cdot \alpha_{1} \\
{ }_{b} M_{Y i}=\left(\sum_{j=i}^{N} m_{j} \cdot \overline{\alpha_{i}}+\sum_{j=i+1}^{N} m_{j} \cdot \overline{\alpha_{i+1}}\right) \frac{H g}{2} \cdot \alpha_{1} \\
\text { こで、 } M=\sum_{j=1}^{N} m_{j}: \text { 総質量 }
\end{array}\right\}
$$

上式の各梁部材端部の降伏曲げモーメントは、基準材端降伏モー メント係数分布 $\bar{\alpha}^{\prime}{ }^{\prime}$ を用いて次式のように表せる。最下部材端降伏モ ーメント係数 $\alpha_{0}^{\prime}=1.0$ とする。

$$
\begin{aligned}
& { }_{b} M_{Y N}=m_{N} \cdot \overline{\alpha_{N}} \cdot \frac{H g}{2} \cdot \alpha_{0}{ }^{\prime} \\
& { }_{b} M_{Y 0}=M \cdot \overline{\alpha_{0}} \cdot \frac{H g}{2} \cdot \alpha_{0}{ }^{\prime} \\
& { }_{b} M_{Y i}=\sum_{j=i}^{N} m_{j} \cdot \overline{\alpha_{i}} \cdot \frac{H g}{2} \cdot \alpha_{0}{ }^{\prime}
\end{aligned}
$$

上記(2)、(3)式より $\bar{\alpha}_{\mathrm{i}}{ }^{\prime}$ は $\bar{\alpha}_{\mathrm{i}}$ と次式で対応づけられる。

$$
\begin{aligned}
& \overline{\alpha_{v}{ }^{\prime}}=\overline{\alpha_{N}} \\
& \overline{\alpha_{0}{ }^{\prime}}=\overline{\alpha_{1}}=1.0 \\
& \overline{\alpha_{i}{ }^{\prime}}=\left(\sum_{j=i}^{N} m_{j} \cdot \overline{\alpha_{i}}+\sum_{j=i+1}^{N} m_{j} \cdot \overline{\alpha_{i+1}}\right) / \sum_{j=i}^{N} m_{j}
\end{aligned}
$$

\section{2 .2 基準損傷分布}

図 1 に示す梁降伏型モデルの損傷の総和 $\mathrm{W}_{\mathrm{P}}$ は、各層梁部材端部 のエネルギー吸収能力。W $W_{\mathrm{Pi}}$ を用いて次式のように書ける。

$$
W_{P}=\sum_{b} W_{P i}
$$

b $\mathrm{W}_{\mathrm{Pi}}$ は梁部材端部の降伏モーメント ${ }_{\mathrm{b}} \mathrm{M}_{\mathrm{Yi}}$ と累積塑性変形角 $\mathrm{b} \theta \mathrm{Pi}$ の積として次式のように表現できる。

$$
\begin{aligned}
{ }_{b} W_{P i}={ }_{b} M_{Y i} \cdot{ }_{b} \theta_{P i} & =\frac{{ }_{b} M_{Y i}{ }_{b} M_{Y i}}{{ }_{b} k_{i}}{ }_{b} \eta_{i} \\
\beth こ て ゙ 、{ }_{b} \theta_{P i} & ={ }_{b} \eta_{i} \cdot{ }_{b} \theta_{Y i} \\
{ }_{b} \eta_{i} & : \text { 累積塑性変形倍率 } \\
{ }_{b} \theta_{Y i} & : \text { 降伏回転角 } \\
{ }_{b} k_{i} & : \text { 梁の曲げ剛性 }
\end{aligned}
$$

梁部材の強度分布が基準状態 $\alpha_{i}^{\prime} / \alpha_{0}^{\prime}=\bar{\alpha}_{i}{ }^{\prime}$ にあるときの、各梁部材間 の損傷比

$$
\begin{gathered}
\frac{{ }_{b} W_{P_{i}}}{{ }_{b} W_{P 0}}=\frac{\left(\sum_{j=i}^{N} m_{j}\right)^{2} \cdot{\overline{\alpha_{i}}}^{\prime} \cdot \frac{H^{2} g^{2}}{4} \cdot \alpha_{0}{ }^{{ }^{2}} \cdot \frac{1}{{ }_{b} k_{i}} \cdot{ }_{b} \eta_{i}}{M^{2} \cdot{\overline{\alpha_{0}}}^{2} \cdot \frac{H^{2} g^{2}}{4} \cdot \alpha_{0}{ }^{\prime 2} \cdot \frac{1}{{ }_{b} k_{0}}{ }_{b} \eta_{0}}=s_{i} \cdot \frac{{ }_{b} \eta_{i}}{{ }_{b} \eta_{0}} \\
\text { ここで、 } s_{i}{ }^{\prime}=\left(\sum_{j=i}^{N} m_{j} / M\right)^{2} \overline{\alpha_{i}{ }^{\prime}}{ }^{2}\left({ }_{b} k_{0} /{ }_{b} k_{i}\right) \\
s_{0}{ }^{\prime}=1.0
\end{gathered}
$$

$\mathrm{s}^{\prime}{ }^{\prime}$ は $\bar{\alpha}_{\mathrm{i}}{ }^{\prime}{ }^{\prime}$ 布に基づく損傷である。

基準状態における梁の損傷分布は、全損傷に占める $\mathrm{i}$ 層上部梁の 損傷の割合として次のように表わすことができる。

$$
\left.\begin{array}{l}
\frac{{ }_{b} W_{P_{i}}}{W_{P}}=\frac{s_{i}{ }^{\cdot}{ }_{b} \eta_{i}}{\sum_{j=0}^{N} s_{j}{ }^{\prime}{ }_{b} \eta_{j}} \\
{ }_{b} \eta_{i}={ }_{b} \eta_{j}
\end{array}\right\}
$$

(4)式で示した骨組が基準状態にあるときの梁材端降伏モーメン 卜係数分布 $\bar{\alpha}_{i}{ }^{\prime}$ 、層数が $5,10,15$ の場合について求める。質量分布 は均一なものとする。骨組の最適降伏せん断力係数分布 $\bar{\alpha}_{\mathrm{i}}$ は次式か ら求められる值となる ${ }^{3)}$ 。

$$
\overline{\alpha_{i}}=f\left(\frac{i-1}{N}\right)
$$

ここで、 $f(x)=1+1.5927 x-11.852 x^{2}+42.583 x^{3}-59.48 x^{4}+30.16 x^{5}$

上式から各骨組の $\bar{\alpha}_{\text {ネ }} \quad \bar{\alpha}^{\prime}{ }^{\prime}$ は以下の值となる。

\author{
5 層骨組 \\ $\bar{\alpha}_{\mathrm{i}}=(1.0,1.1,1.25,1.52,2.0)$ \\ $\bar{\alpha}_{1}^{\prime}=(1.0,1.88,2.04,2.27,2.53,2.0)$
}

\section{0 層骨組}

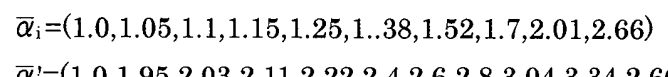




\section{5 層骨組}

$$
\begin{aligned}
\bar{\alpha}_{\mathrm{i}}= & (1.0,1.03,1.07,1.1,1.13,1.18,1.25,1 . .34,1.43,1.52,1.63,1.78, \\
& 2.01,2.39,3.01)
\end{aligned}
$$

$\bar{\alpha}_{1}^{\prime}=(1.0,1.96,2.02,2.08,2.13,2.2,2.31,2.44,2.58,2.73,2.88,3.06$,

$3.29,3.6,3.89,3.0)$

図 2 に 5,10,15 層骨組の $\bar{\alpha}^{\prime}$ 'を示す。(4)式において $\sum_{j=i}^{N} m_{j} \fallingdotseq \sum_{j=i+1}^{N} m_{j}$ 、 $\bar{\alpha}_{i} \fallingdotseq \bar{\alpha}_{i+1}$ と考えれば、 $\bar{\alpha}_{i}{ }^{\prime} \fallingdotseq 2 \bar{\alpha}_{i}$ である。図中の点線は位で、(9)式か ら単一化曲線として表される。実線はこの京を 2 倍した $2 \bar{\alpha}_{\mathrm{i}}$ あるる。 図の縦軸は、各節点を相対高さとして表した(i-1)/Nである。ただし、 $\bar{\alpha}_{0}^{\prime}$ の縦軸の位置は 0 とする。図から $\bar{\alpha}_{i}{ }^{\prime}$ 梳最適降伏せん断力係数分 布 $\bar{\alpha}_{\mathrm{i}}$ と同様に、その值は層数が増えるほど大きくなる傾向にある。

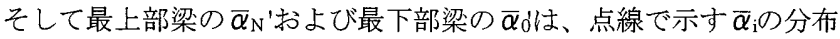
と一致し、一般層上部梁の $\bar{\alpha}^{\prime}{ }^{\prime}$ は実線で示す $2 \bar{\alpha}_{\mathrm{i}}$ の分布とほぼ一致す る。

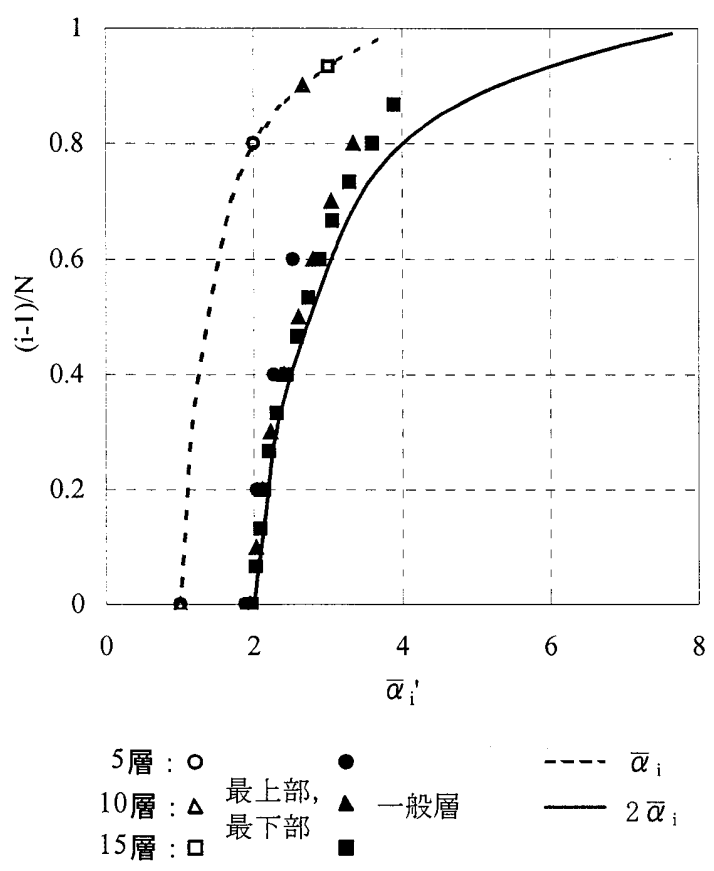

図 2 降伏モーメント係数分布 $\bar{\alpha}_{i}^{\prime}$

(8)式の損傷分布の予測値を求めるのに必要な、図 2 に示した $\bar{\alpha}_{i}{ }^{\prime}$ に基づく梁部材の損傷 $\mathrm{si}^{\prime}$ の分布を図 3 に示す。(4)式に示すように、 $\bar{\alpha}_{\mathrm{N}}=\bar{\alpha}_{\mathrm{N}} \quad \bar{\alpha}_{0}^{\prime}=\bar{\alpha}_{1}$ であることから $\mathrm{sN}^{\prime}=\mathrm{s}_{\mathrm{N}} 、 \mathrm{~s}^{\prime}=\mathrm{s}_{1}$ である。また $\bar{\alpha}_{\mathrm{i}}{ }^{\prime}=2 \bar{\alpha}_{\mathrm{i}}$ であることから、 $\mathrm{s}^{\prime} \fallingdotseq 2 \mathrm{~s}_{\mathrm{i}}$ である。図中の点線は

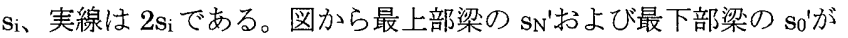
点線で示す $\mathrm{si}_{\mathrm{i}}$ と、一般層上部梁の $\mathrm{si}_{\mathrm{i}}$ が実線で示す $2 \mathrm{si}_{\mathrm{i}}$ とほぼ一致し、 図 2 で示した $\bar{\alpha}^{\prime}{ }^{\prime}$ と $\bar{\alpha}_{\mathrm{i}}$ の関倸と同様のものとなった。これらの結果 から、 $\bar{\alpha}^{\prime}{ }^{\prime}$ と $\mathrm{s}_{\mathrm{i}}{ }^{2}$ はそれぞれ $\bar{\alpha}_{\mathrm{i}}$ と $\mathrm{s}_{\mathrm{i}}$ のおよそ 2 倍、最上部の $\bar{\alpha}_{\mathrm{N}}{ }^{\prime} 、 \mathrm{SN}^{\prime}$ 、 最下部の $\bar{\alpha}_{0}^{\prime} 、 s_{0}^{\prime} は \bar{\alpha}_{\mathrm{i}} \mathrm{si}_{\mathrm{i}}$ で表すことができる。
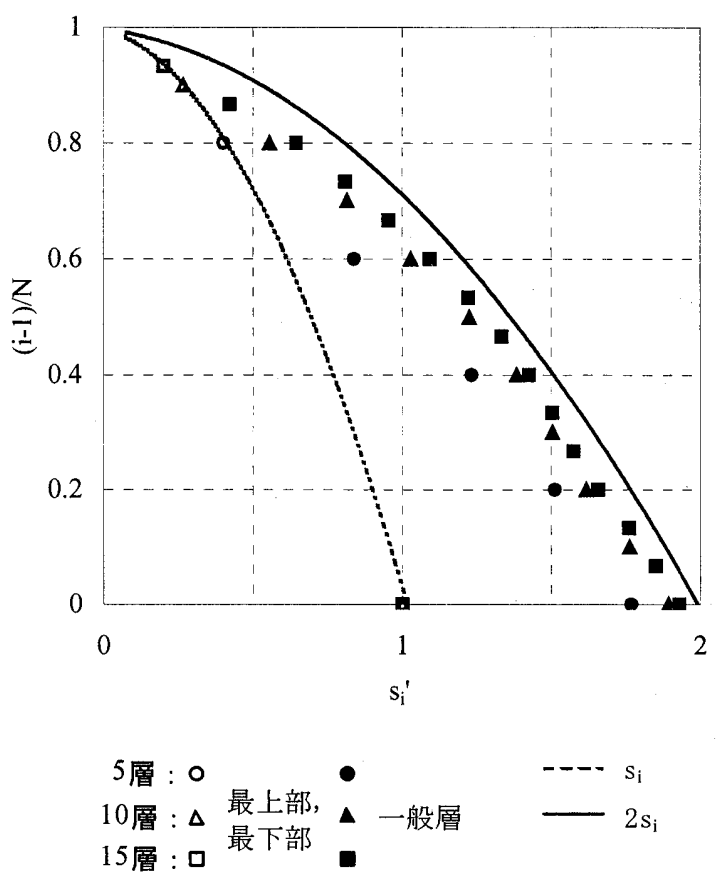

図 3 損傷分布予測

\section{2 .3 基準骨組の応答}

無減衰多質点系モデルを用いた応答解析を行い、基準骨組の損傷 分布を示す。質点数は $\mathrm{N}=5,10,15$ の 3 種類、骨組は部材端部に完全 弾塑性型の復元力特性を持つばるを有する部材モデルで、2．損傷 分布の基準状態の項で示した梁降伏型魚骨モデルと同様のモデルで ある。各質点系の弾性 1 次固有周期は次式による値とした ${ }^{5)}$

$$
\left.\begin{array}{ll}
T=0.2 N & (N \leqq 5) \\
T=0.55+0.085 N & (N>6)
\end{array}\right\}
$$

上式より各質点系の弾性 1 次固有周期は次のようになる。

$\mathrm{N}=5: \mathrm{T}=1.0 \mathrm{~s}$

$\mathrm{N}=10: \mathrm{T}=1.4 \mathrm{~s}$

$\mathrm{N}=15: \mathrm{T}=1.8 \mathrm{~s}$

入力地震波は El Centro-NS と八戸-EW の 2 種類、解析パラメータ 一は梁の曲げ剛性 $\mathrm{b} \mathrm{k}$ に対する柱の曲げ剛性 $\mathrm{ck}$ の比を表す梁柱剛性 比 $\mathrm{k}_{\mathrm{bc}}(=\mathrm{b} \mathrm{k} / \mathrm{ck})$ と梁材端の累積塑性変形倍率 ${ }_{\mathrm{b}} \eta_{\mathrm{i}}$ で、 $\mathrm{k}_{\mathrm{bc}}$ は 1.0 及び 2.0 、 b $\eta_{\mathrm{i}}$ は 10.0 で各部材一定となるようにした。図4に解析結果を示す。 図の縦軸は各節点を相対高さとして表した(i-1)/N、横軸は最下部梁 損傷に対する各節点梁損傷の割合 および最下部梁の損傷分布を示しており、図中の点線は 損傷分布 $s_{i}$ である。図 4b)は一般層上部梁の損傷分布を示しており、 実線は $2 \mathrm{~s}_{\mathrm{i}}$ である。図から層数や $\mathrm{k}_{\mathrm{bc}}$ の大きさにより若干の違いは見 られるが、いずれの応答もほぼ同様の傾向を示し、その值は最上部 と最下部で $\mathrm{s}_{\mathrm{i}} 、$ 一般層で $2 \mathrm{~s}_{\mathrm{i}}$ とほぼ一致する。 


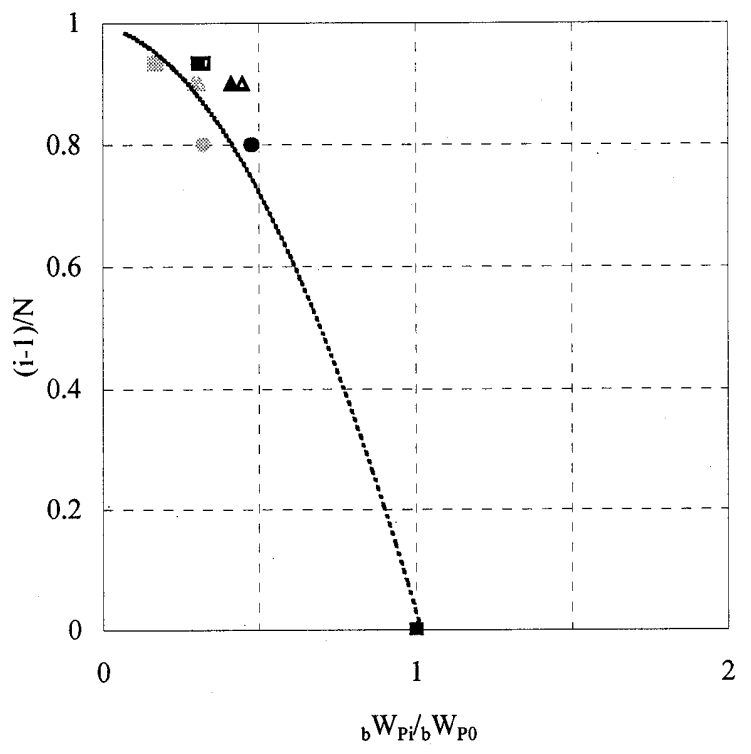

a ）最上部、最下部

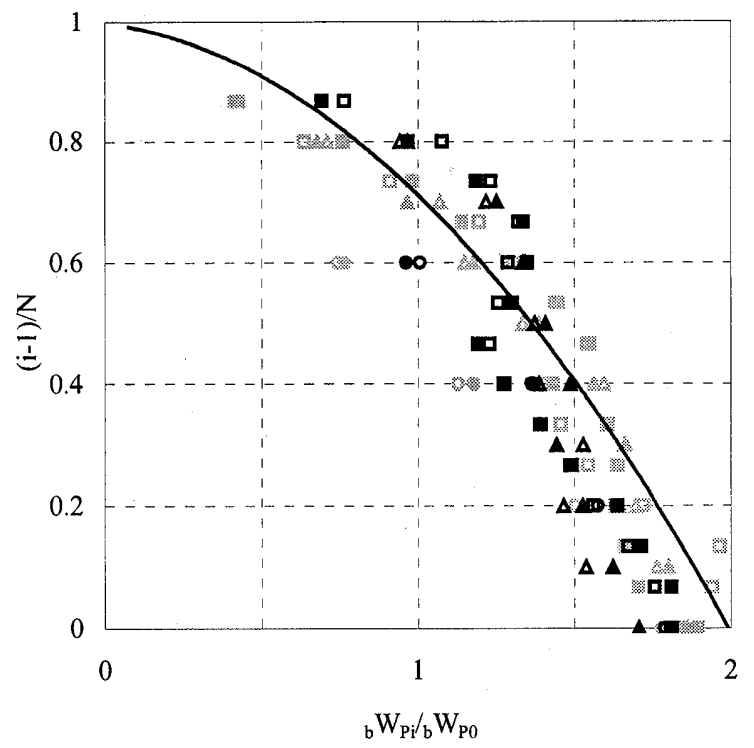

b ）一般層上部

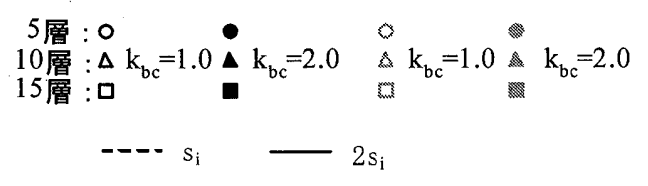

図 4 基準状態の損傷分布

\section{3．基本損偒分布則}

梁降伏型多層骨組において、各部材の損傷が一定となるような強 度分布を最適分布としたとき、この強度分布の最適分布からのずれ が損傷集中要因として支配的であると考え、強度分布が最適值から はずれる場合の各層上部梁部材ごとの損傷分布を次式のように表す。

$$
\begin{gathered}
\frac{{ }_{b} W_{p i}}{W_{p}}=\frac{s_{i}{ }_{i} p_{i}{ }^{\prime-n}}{\sum_{j=0}^{N} s{ }^{\prime} p_{j}{ }^{\prime-n}} \\
こ こ て ゙, p_{j}{ }^{\prime}=\frac{\alpha_{j}{ }^{\prime}}{\alpha_{0}{ }^{\prime}{ }^{\prime}{ }_{j}^{\prime}} \\
p_{j}{ }^{\prime}: \text { 梁部材端部降伏応力の最適値加らの偏差 } \\
n: \text { 損傷集中指数 }
\end{gathered}
$$

$\mathrm{p}_{\mathrm{j}}{ }^{\prime}$ は梁降伏型骨組の $\mathrm{j}$ 層上部梁部材端部降伏強度の最適值からの 隔たりの度合いを示す。 $\mathrm{n}$ は損傷を支配する正の指数であり、損傷 集中指数と呼ぶ。n が大きいほど、 $\mathrm{p}_{\mathrm{j}}$ へのの損傷配分の依存度が増加 する。

\section{4. 損傷集中指数 $n$}

$4.1 p_{d}$ への依存性

損傷集中指数 $\mathrm{n}$ の值は、着目する一つの部材に降伏耐力の低下を もたらす場合の損傷分布の変化から求めることができる。まず基準 状態の骨組において、着目する $\mathrm{i}$ 層上部梁部材端部の損傷分布を求 め $\mathrm{a}$ と置く。次に着目する梁部材端部の降伏耐力を基準状態の $\mathrm{p}_{\mathrm{d}}\left(\mathrm{p}_{\mathrm{d}}<1.0\right)$ 倍した場合の損傷分布を $\mathrm{b}$ と置く。これら $\mathrm{a}, \mathrm{b}, \mathrm{p}_{\mathrm{d}}$ を用い てn㳄式で表される。

$$
\begin{gathered}
n=-\ln \left\{\frac{b(1-a)}{a(1-b)}\right\} / \ln p_{d} \\
\text { ここで、 } \quad a=\frac{{ }_{b} W_{p i}}{W_{p}}=\frac{s_{i}^{\prime} p_{i}{ }^{\prime-n}}{\sum_{j=0}^{N} s_{j}{ }_{j} p_{j}{ }^{\prime-n}} \\
b=\frac{{ }_{b} W_{p i}}{W_{p}}=\frac{s_{i}{ }^{\prime} p_{i}{ }^{\prime-n} p_{d}{ }^{-n}}{\sum_{j \neq i}^{N} s_{j}{ }^{\prime} p_{j}{ }^{\prime-n}+s_{i}{ }^{\prime} p_{i}{ }^{\prime-n} p_{d}{ }^{-n}} \\
p_{d}{ }^{-n}=\frac{b(1-a)}{a(1-b)}
\end{gathered}
$$

基準状態 $\left(\mathrm{p}_{\mathrm{j}}{ }^{\prime}=1,0, \mathrm{n}=0\right)$ にある骨組を初期状態に設定し、特定の部 材に $\mathrm{p}_{\mathrm{d}}$ を与え、2.2.3 基準骨組の応答の項と同様の応答解析を行 い（12)式から $\mathrm{n}$ の值を求め図 5 に示す。 $\mathrm{p}_{\mathrm{d}}$ を与えた特定の部材は 最下部、中間層上部、最上部梁である。図中の実線および点線で示 される $\mathrm{n}$ の值は、秋山により求められ、現実的な值とされる柱降伏 型の $\mathrm{n}=12^{2}$ 、梁降伏型の $\mathrm{n}=6^{6}$ )である。図から層数や梁の位置にか かわらず、 $\mathrm{p}_{\mathrm{d}}$ が 1.0 に近付くにつれて $\mathrm{n}$ が大きくなる傾向が見られ る。 $\mathrm{p}_{\mathrm{d}}=1.0$ は最適な強度分布を持つ場合であり、最適分布からのず れが小さくても損傷集中の恐れがあることを示している。またこの 傾向は梁柱剛性比 $\mathrm{k}_{\mathrm{bc}}$ が大きくなるほど大きくなり、 $\mathrm{k}_{\mathrm{bc}}=10.0$ では $\mathrm{n}$ の值は 12 前後になる。このことから梁剛性が柱剛性に比べて高く なることにより、魚骨モデルにおける梁降伏型骨組の損傷の傾向が、 せん断型モデルにおける柱降伏型骨組の損傷の傾向に近付くことが わかる。実構造物における梁剛性と柱剛性の関係から k $\mathrm{k}_{\mathrm{bc}}$ の上限を 2.0 程度と考え、文献 3 )にならい $\mathrm{p}_{\mathrm{d}}=0.8$ に対応する $\mathrm{n}$ の値を設計值 とすると、図 $5 \mathrm{~b}$ )に示すように $\mathrm{n}$ の上限值はおおよそ 6 である。 


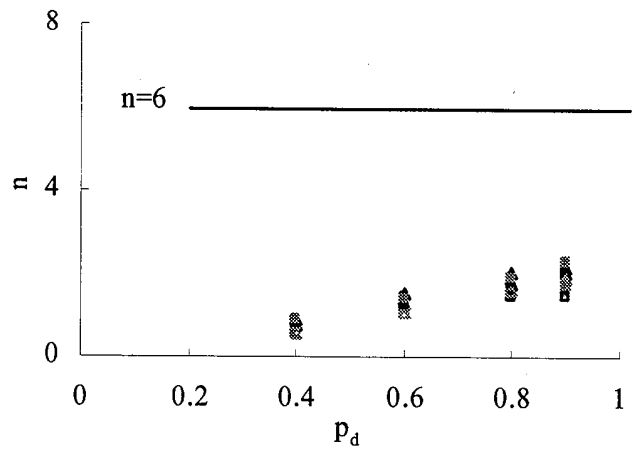

a ) $\mathrm{k}_{\mathrm{bc}}=0.1$

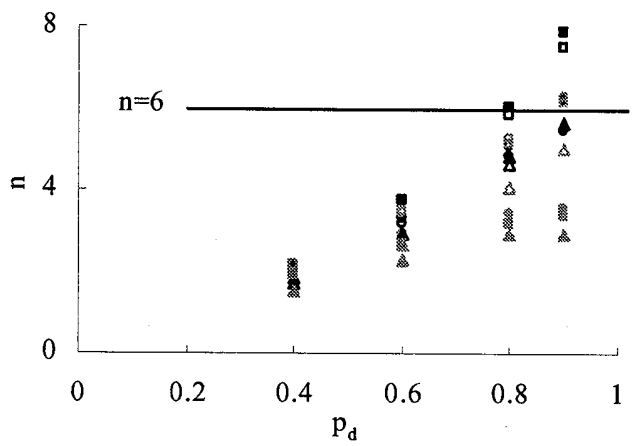

b) $\mathrm{k}_{\mathrm{bc}}=2.0$

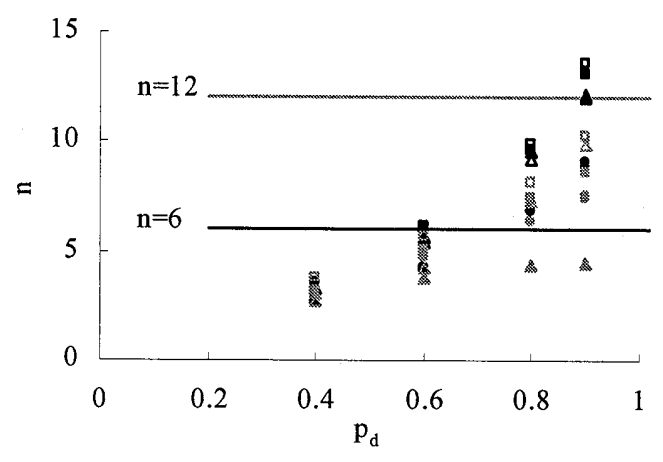

c) $\mathrm{k}_{\mathrm{bc}}=10.0$

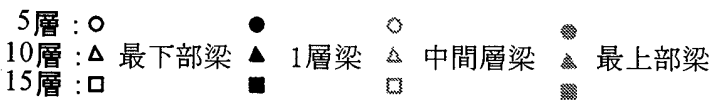

図 $5 n-p_{d}$ 関倸

\section{2 梁の損傷集中特性}

$\mathrm{p}_{\mathrm{d}}$ を与えた特定の梁部材の損傷集中特性をエネルギ一集中比 2) と して、図 6 に $\mathrm{p}_{\mathrm{l}}$ との関係で示す。エネルギー集中比は基準状態にあ る骨組において、任意の部材の降伏耐力が最適状態である場合に対 する、最適状態からはずれる場合の比 図の縦軸がエネルギー集中比、横軸は $\mathrm{p}_{\mathrm{d}}$ の逆数で $\mathrm{p}_{\mathrm{d}}{ }^{1}$ である。 $\mathrm{p}_{\mathrm{d}}{ }^{1}$ は值が大きくなるほど強度分布が最適分布から離れることを意味す る。また(11)式の指数 $\mathrm{n}$ を 6 としたときの予測值を実線で示寸。 $\mathrm{k}_{\mathrm{bc}}=1.0,2.0$ の骨組の場合、図から $\mathrm{n}$ の值は層数にかかわらず、 $\mathrm{n}=6$ の予測值内でほぼ収まっていることがわかる。
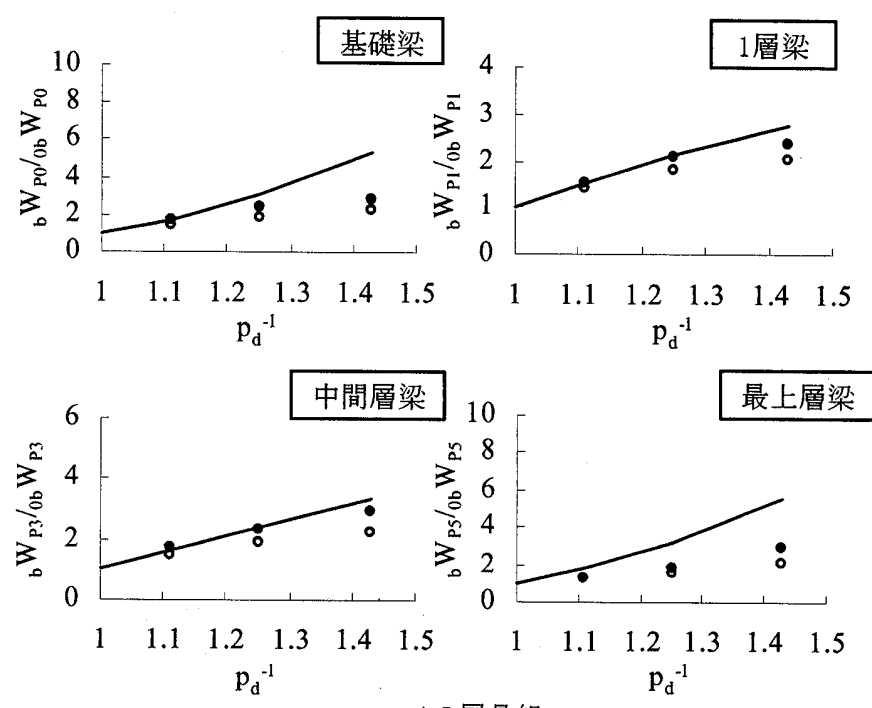

a) 5 層骨組
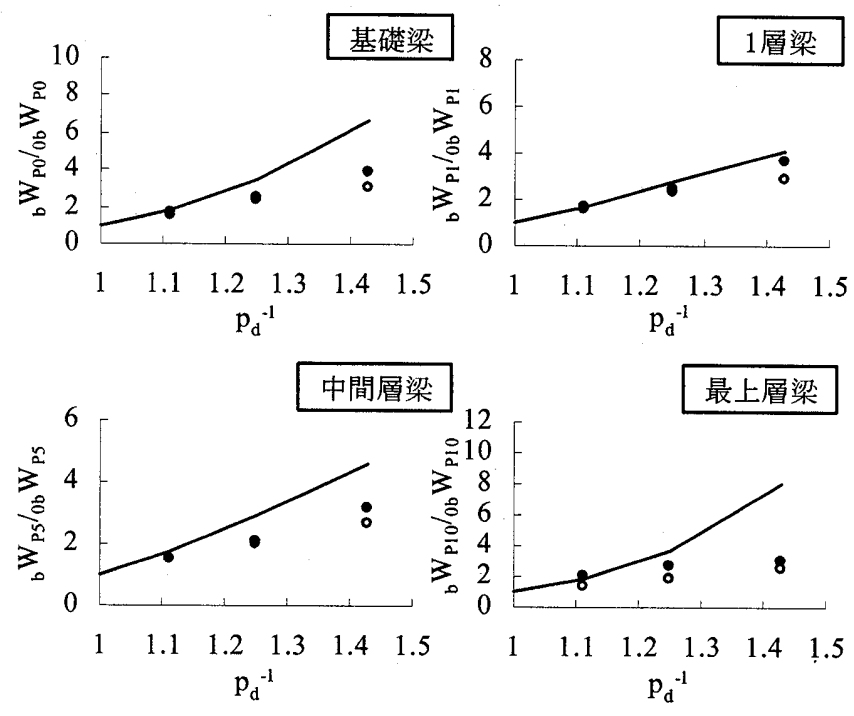

b) 10 層骨組
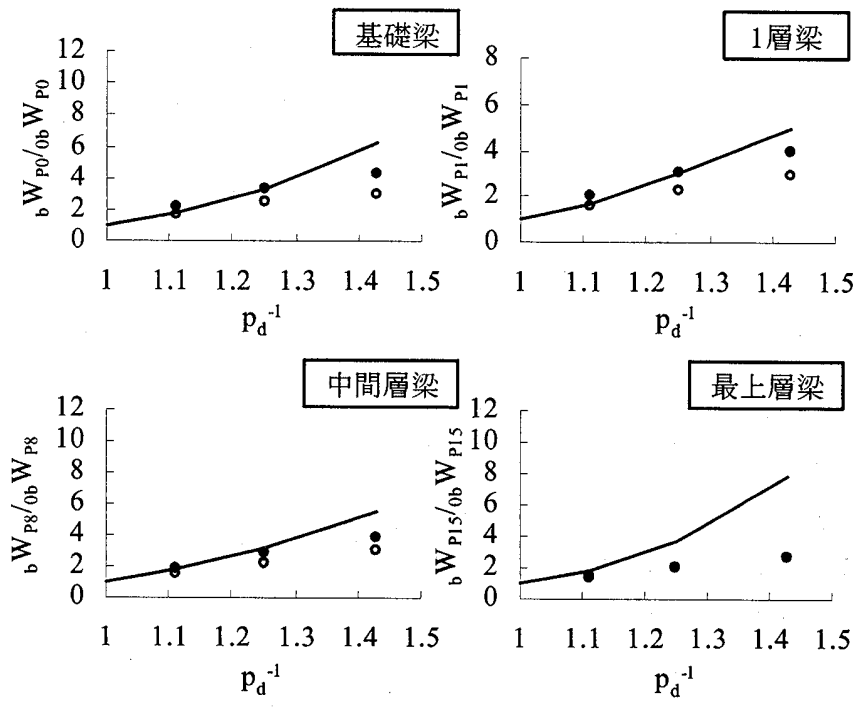

c ) 15 層骨組

$\circ \mathrm{k}_{\mathrm{bc}}=1.0 \bullet \mathrm{k}_{\mathrm{bc}}=2.0$ 予測值 $\mathrm{n}=6$

図 6 梁部材の損傷集中特性 


\section{3 梁柱剛性比 $k_{b c}$ の影響}

梁と柱の剛性の関係により、梁降伏型骨組の損傷集中指数 $\mathrm{n}$ の值

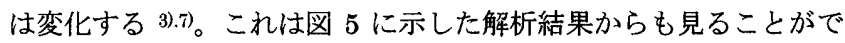
きる。そこで、 $\mathrm{n}$ の值を梁柱剛性比 $\mathrm{k}_{\mathrm{bc}}$ との関係として求める。図 7 は $\mathrm{p}_{\mathrm{d}}=0.8$ として $\mathrm{k}_{\mathrm{bc}}$ を変化させたときの $\mathrm{n}$ の值である。図中の点線 は、せん断型多層骨組の損傷分布則における梁降伏型骨組の $\mathrm{n}$ 值 ${ }^{3}$ を示している。図からもわかるように、 $\mathrm{n}$ は $\mathrm{k}_{\mathrm{bc}}$ の増加関数となり、 近似的に次式で表され、図中の実線で示すようになる。

$$
n=3+1.6 k_{b c}
$$

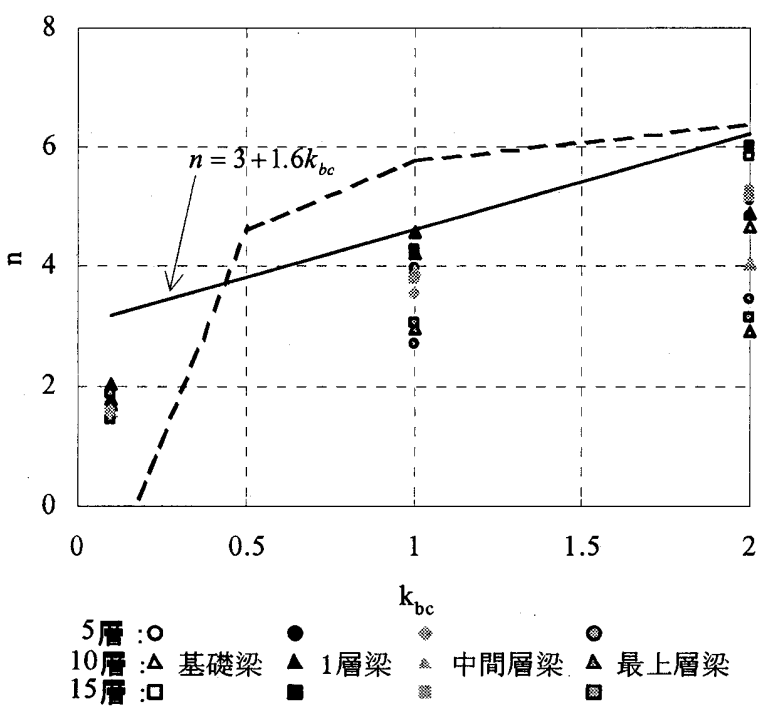

図 $7 n-k_{b c}$ 関倸

\section{5. まとめ}

部材レベルの変形を評価できる魚骨モデルを用いて、文献 3)と同 様の手法により、完全弾塑性型復元力特性部材を持つ、梁降伏型骨 組の損傷分布則を部材レベルの予測式として示した。

1) 梁降伏型魚骨モデルには、各部材の損傷が等しくなるような強度 分布 $\boldsymbol{\alpha}^{\prime}$ が存在し、その分布は最上部と最下部の梁で最適降伏せん 断力倸数分布 $\bar{\alpha}_{\mathrm{i}}$ と、一般層上部梁で $2 \bar{\alpha}_{\mathrm{i}}$ とほぼ等しく表せる。

2) 梁降伏型魚骨モデルの材端降伏モーメント倸数分布 $\bar{\alpha}_{i}$ "に対応す る損傷分布の予測值 $s_{i}^{\prime}$ は、最上部と最下部で $\bar{\alpha}_{i}$ に対応する $s_{i}$ と、 一般層上部で $2 \mathrm{si}_{\mathrm{i}}$ と等しく表すことができる。応答解析結果も層 数や梁柱岡性比 $\mathrm{k}_{\mathrm{be}}$ の大きさにかかわらず、予測值と概ね対応す ることから、予測式の有効性を確認した。

3) 梁降伏型骨組の現実的な損傷集中指数 $\mathrm{n}$ の值として秋山は $\mathrm{n}=6$ を提案しているが、部材レベルで検討した今回の結果からも、 $\mathrm{k}_{\mathrm{bc}}$ $\leqq 2.0$ の範囲で $\mathrm{n}$ の上限值が 6 となった。

4) n の值は梁柱剛性比 $\mathrm{k}_{\mathrm{bc}}$ が大きくなるほど大きくなる傾向があり、 $\mathrm{n}$ の值を $\mathrm{kbc}_{\mathrm{bc}}$ の増加関数として、近似的に(13)式で表した。

\section{参考文献}

1）加藤勉,秋山宏：強震時による構造物へのエネルギ入力と䊦造物の損傷, 日本建築学会論文報告集 第 235 号, pp9·18，1975.9.

2）加藤勉,秋山宏：地震時における鈵構造せん断型多層骨組の損傷分布則, 日本建築学会論文報告集 第 270 号, pp61-68, 1978.8 .

3）秋山宏：梁降伏型銅構造多層剛接骨組の $D_{s}$ 値, 日本建築学会論文報告集 第 332 号, pp38-46, 1983.10

4）小川厚治,加村久哉,井上一朗：銅構造ラーメン骨組の魚骨形地震応答解析 モデル，日本建築学会棒造系論文集 第 521 号, pp119-126，1999.7.

5）社団法人 鋼材俱楽部：中低層鉄骨建物の而震設計法, 技報堂出版, pp471·484, 1983.

6）秋山宏：地震時における鋼構造ラーメン骨組の損傷分布則, 日本建築学 会論文報告集第 309 号, pp53-59, 1981.11.

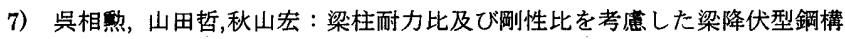
造多層骨組の損甥分布則, 日本建築学会構造系論文集 第 506 号, pp171·177, 1998.4 